\title{
Normal reference ranges for biochemical substances relating to renal, hepatic, and bone function in fetal and maternal plasma throughout pregnancy
}

\author{
CF MONIZ, ${ }^{*} \mathrm{KH}$ NICOLAIDES,$\dagger$ FJ BAMFORTH,${ }^{*} \ddagger \mathrm{CH}$ RODECK $\dagger$ \\ From the *Department of Chemical Pathology and the †Harris Birthright Research Centre for Fetal Medicine, \\ King's College School of Medicine and Dentistry, London SE5
}

SUMMARY Normal reference ranges for sodium, potassium, urea, creatinine, calcium, phosphate, total protein, albumin, bilirubin, alkaline phosphatase, and aspartate transaminase were determined from 344 fetal and maternal plasma samples between 15 and 38 weeks' gestation. Pure fetal blood was obtained by fetoscopy in the second trimester and in the third trimester by umbilical cord puncture at delivery. All biochemical substances were measured by continuous flow (SMAC, Technicon) except albumin, which was measured by turbidimetry (CobasBio, Roche). The resulting data were analysed on an AMDAHL 470A computer and reference ranges covering 2.5 to 97.5 percentiles were defined. Analysis of variance was performed to examine the overall effect of gestational age on the analytes measured and on the changes in the fetal compartment relative to the mothers'. A paired test was performed to examine how these biochemical substances in fetal plasma related to maternal plasma from the same pregnancy.

Ultrasonography, amniocentesis, fetoscopy, and more recently chorionic villus biopsy have led to an increase in the detection of fetal abnormalities and diseases. These techniques have encouraged a variety of direct interventions in utero for the correction of underlying defects.'

With the aim of obtaining a better understanding of normal fetal biochemistry we have studied the changes in commonly measured biochemical analytes relating to renal, hepatic, and bone function in fetal blood and their relation to maternal blood throughout gestation. This knowledge will enable a more rational approach to the diagnosis and treatment of conditions such as unexplained fetal hydrops, intrauterine growth retardation, and fetal obstructive uropathy. To this end, we have been able to analyse pure fetal blood samples obtained by fetoscopy ${ }^{12}$ from live fetuses in the second trimester of pregnancy and from cord blood at delivery.

\section{Patients and methods}

A cross sectional study was undertaken. Fetal and maternal blood samples were obtained from 344

†Present address: Welsh National School of Medicine, Cardiff.

Accepted for publication 19 December 1984 normal pregnancies of between 15 and 38 weeks' gestation. The gestational age was determined by calculation from the date of the last menstrual period and confirmed by ultrasonography. Pure fetal blood samples in the second trimester of pregnancy were obtained fetoscopically from 135 pregnancies. The procedure was performed for the prenatal diagnosis of a variety of conditions, ${ }^{3}$ but for the present study only samples from pregnancies with a normal outcome were selected. Fetoscopy was performed with a $1.7 \mathrm{~mm}$ diameter Olympus Selfscope, housed in a $2.4 \times 3.0 \mathrm{~mm}$ diameter cannula. A full aseptic technique was employed to introduce the fetoscope transabdominally into the amniotic cavity and the site of uterine entry was chosen by detailed real time ultrasound scanning ${ }^{4}$ to avoid damage to either the fetus or placenta while gaining access to the placental insertion of the umbilical cord. The patient was sedated to reduce maternal and fetal movements during these procedures. Two millilitres of pure fetal blood was obtained from each fetus by this technique. The blood not used for the diagnostic test was transferred into labelled heparinised Vacutainers (Becton and Dickinson) for the biochemical analysis.

In the third trimester of pregnancy fetal blood (from 209 fetuses) was obtained by umbilical cord 468 
Table 1 Analytical methods used in this study

\begin{tabular}{ll}
\hline Analyte & Method \\
\hline $\begin{array}{l}\text { Sodium } \\
\text { Potassium }\end{array}$ & $\begin{array}{l}\text { Ion selective electrode (indirect) } \\
\text { Ion selective electrode (indirect) } \\
\text { Urea }\end{array}$ \\
$\begin{array}{l}\text { Diacetyl monoxime } \\
\text { Calcium }\end{array}$ & $\begin{array}{l}\text { Jaffe alkaline picrate } \\
\text { Phosphate }\end{array}$ \\
$\begin{array}{l}\text { Cresolpthalein complexone } \\
\text { Albumin }\end{array}$ & $\begin{array}{c}\text { Ammonium molybdate at } 340 \mathrm{~nm} \\
\text { Biuret with blank channel }\end{array}$ \\
$\begin{array}{l}\text { Bilirubin } \\
\text { Aspartate transaminase } \\
\text { (EC 2.6.1.1.) }\end{array}$ & $\begin{array}{l}\text { Bromocresol green in } \\
\text { succinate buffer }\end{array}$ \\
$\begin{array}{l}\text { Alkaline phosphatase } \\
\text { (EC 3.1.3.1.) }\end{array}$ & $\begin{array}{c}\text { Caffeine-benzoate } \\
\text { Alanine oxaloacetate (37 }\end{array}$ \\
\hline
\end{tabular}

puncture after vaginal delivery or at caesarian section from births with a live outcome. Maternal blood from the antecubital vein was also collected into Vacutainers in each case. Samples were centrifuged at $500 \mathrm{~g}$ for $10 \mathrm{~min}$ between 30 and $60 \mathrm{~min}$ after collection; the plasma was analysed within $4 \mathrm{~h}$ of collection on a multichannel continuous flow analyser (SMAC, Technicon, Basingstoke).

Table 1 summarises the techniques used on the SMAC for the 11 biochemical indices. Reagents were prepared as directed by the manufacturers. The SMAC was calibrated using two calibrators, Calibrator Technicon "Ref-1" cat no T037020 and Ref- 3 cat no T037220. Internal quality control was performed using Armatrol Control sera (Purce Associates Ltd) at three different levels and these were interspersed every 15 samples during analysis. The batch was accepted only if the internal quality control values were within specified limits. Quality assessment was monitored with the use of two schemes, the United Kingdom External Quality Assurance Scheme (UKEQAS) and the Wellcome Group Quality Control Programme for Biochemical Indices. In the period during which the data were collected the running overall mean variance index score $^{5}$ was never above $48 \%$. In the Wellcome Reagent Group scheme, for the two year period under study, the variance index score (VIS) was used to calculate the mean VIS and standard deviation of VIS for each analyte. Using the published calculated coefficient of variation we were able to assess the percent accuracy and percent precision for each chemistry over a wide range of concentrations analysed in the two year period during which this study was undertaken (Table 2). Albumin was measured by turbimetry ${ }^{6}$ on the Cobas Bio Centrifugal analyser (Wellwyn Garden City), and performance was assessed using commercial controls (Armatrol).

Alkaline phosphatase isoenzymes in 12 cases were characterised by heat inactivation studies using
Table 2 Analytical performance of the assays during the period of this study

\begin{tabular}{lcl}
\hline Analyte & \% Accuracy & \% Precision \\
\hline Sodium & 0.06 & 1.28 \\
Potassium & 0.17 & 2.09 \\
Urea & -0.19 & 2.5 \\
Creatinine & 0.57 & 4.7 \\
Calcium & 0.60 & 1.4 \\
Phosphate & 2.9 & 1.7 \\
Total protein & 2.30 & 1.7 \\
Albumin & 1.03 & 2.2 \\
Bilirubin & -6.6 & 6.4 \\
Aspartate transaminase & 10.1 & 6.6 \\
Alkaline phosphatase & 7.5 & 5.0 \\
\hline
\end{tabular}

the method of Whitby and Moss ${ }^{7}$ and also separated electrophoretically on agarose gels (Sigma).

\section{STATISTICAL ANALYSIS}

The data were coded, verified, and analysed in an IBM AMDAHL 470A computer. The respective distributions were examined and outliers were eliminated. Some analytes showed a non-Gaussian distribution, and following recommendations made with regards to reference values 8 the data were log transformed to normalise the distribution. The mean value was determined and the percentile limits $2 \cdot 5$ 97.5 were chosen to cover $95 \%$ of the population. Analysis of variance on the log transformed data was computed to examine the overall influence of gestational age on the 11 analytes measured. For each analyte the difference in concentration in maternal and fetal plasma was determined and an analysis of variance on these data was performed to show how fetal plasma constituents related to mothers' throughout gestation. A paired $t$ test showed how the biochemical analytes in fetal plasma related to maternal ones in each gestational group.

\section{Results and discussion}

The results (mean and range) for each of the 11 biochemical analytes in fetal and maternal plasma are shown in Tables 3 and 4 respectively. In the analysis of variance of these data there is an overall change with gestational age in all substances measured except electrolytes (Table 5). Analysis of variance on the difference in concentration in substances in maternal and fetal plasma with gestation show that these overall changes in the two compartments occur independently (Table 6).

\section{ELECTROLYTES}

Sodium and potassium concentrations in both fetal and maternal plasma showed no change with gestational age. These results indicate that the developing fetus is remarkably efficient in maintaining the electrolyte concentration of it's plasma constant 
Table 3 Biochemical values in fetal plasma throughout gestation (mean, range)

\begin{tabular}{|c|c|c|c|c|c|c|}
\hline & \multicolumn{6}{|c|}{ Gestation (wk) } \\
\hline & $15-18$ & $19-22$ & $23-26$ & $27-30$ & $31-34$ & $35-38$ \\
\hline 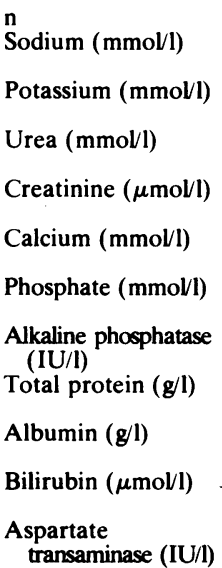 & $\begin{array}{l}79 \\
136 \\
(132-140) \\
3 \cdot 6 \\
(3 \cdot 1-4 \cdot 1) \\
2 \cdot 8 \\
(2 \cdot 0-3 \cdot 7) \\
36 \\
(30-47) \\
2 \cdot 15 \\
(2 \cdot 03-2 \cdot 30) \\
1 \cdot 15 \\
(1 \cdot 05-1 \cdot 25) \\
127 \\
(85-170) \\
27 \\
(22-30) \\
16 \\
(13-19) \\
12 \\
(8-15) \\
15 \\
(10-25)\end{array}$ & $\begin{array}{l}38 \\
136 \\
(132-139) \\
3 \cdot 6 \\
(3 \cdot 1-4 \cdot 1) \\
3 \cdot 2 \\
(2 \cdot 1-4 \cdot 3) \\
41 \\
(32-52) \\
2 \cdot 22 \\
(2 \cdot 07-2 \cdot 37) \\
1 \cdot 11 \\
(0 \cdot 86-1 \cdot 36) \\
162 \\
(83-221) \\
30 \\
(24-37) \\
18 \\
(14-22) \\
10 \\
(5-15) \\
16 \\
(7-37)\end{array}$ & $\begin{array}{l}18 \\
135 \\
(130-139) \\
3 \cdot 5 \\
(3 \cdot 4-3 \cdot 7) \\
3 \cdot 4 \\
(2 \cdot 7-4 \cdot 1) \\
42 \\
(33-50) \\
2 \cdot 15 \\
(2 \cdot 01-2 \cdot 29) \\
1 \cdot 15 \\
(1 \cdot 05-1 \cdot 25) \\
171 \\
(114-299) \\
36 \\
(32-39) \\
23 \\
(19-27) \\
8 \\
(2-15) \\
20 \\
(8-34)\end{array}$ & $\begin{array}{l}22 \\
136 \\
(134-138) \\
3 \cdot 6 \\
(3 \cdot 4-3 \cdot 8) \\
3 \cdot 0 \\
(2 \cdot 2-3 \cdot 8) \\
42 \\
(34-50) \\
2 \cdot 32 \\
(2 \cdot 24-2 \cdot 39) \\
1 \cdot 13 \\
(0 \cdot 93-1 \cdot 28) \\
211 \\
(101-322) \\
43 \\
(36-48) \\
29 \\
(23-35) \\
20 \\
(5-29) \\
20 \\
(9-47)\end{array}$ & $\begin{array}{l}25 \\
135 \\
(133-137) \\
3 \cdot 5 \\
(3 \cdot 2-3 \cdot 8) \\
3 \cdot 3 \\
(2 \cdot 8-3 \cdot 8) \\
43 \\
(32-54) \\
2 \cdot 31 \\
(2 \cdot 20-2 \cdot 43) \\
1 \cdot 10 \\
(0 \cdot 83-1 \cdot 37) \\
257 \\
(152-342) \\
43 \\
(35-50) \\
32 \\
(25-40) \\
27 \\
(5-35) \\
26 \\
(11-49)\end{array}$ & $\begin{array}{l}162 \\
136 \\
(132-140) \\
3 \cdot 6 \\
(3 \cdot 1-4 \cdot 1) \\
3 \cdot 3 \\
(2 \cdot 8-3 \cdot 9) \\
47 \\
(32-65) \\
2 \cdot 39 \\
(2 \cdot 23-2 \cdot 55) \\
1 \cdot 10 \\
(0 \cdot 91-1 \cdot 20) \\
270 \\
(134-395) \\
59 \\
(49-69) \\
32 \\
(27-36) \\
20 \\
(2-29) \\
18 \\
(7-43)\end{array}$ \\
\hline
\end{tabular}

throughout gestation, despite large fluxes in water and sodium. ${ }^{10}$

\section{UREA AND CREATININE}

There was an overall significant increase in the concentration of urea and creatinine in fetal plasma, but when the changes were examined in individual gestational groups the concentrations were not different in the two compartments until 20-22 weeks' gestation $(\mathrm{t}=0.4, \mathrm{p}>0.05$, paired Student's $\mathrm{t}$ test). In animal studies, fetal plasma urea concentrations were higher than maternal values, with a constant fetal-maternal concentration gradient across the placenta, over a wide range of urea concentrations. " It is possible that creatinine, like urea, also has a constant diffusion rate and the rise in fetal plasma creatinine reflects the increases in fetal muscle mass rather than a decrease in renal function. In addition, account must be taken of non-creatinine reacting substances in plasma ${ }^{12}$ that could contribute significantly in the assay of creatinine, particularly at low values. Maternal plasma urea and creatinine

Table 4 Biochemical values in maternal plasma in the same pregnancy throughout gestation (mean, range)

\begin{tabular}{|c|c|c|c|c|c|c|}
\hline & \multicolumn{6}{|l|}{ Gestation (wk) } \\
\hline & $15-18$ & $19-22$ & $23-26$ & $27-30$ & $31-34$ & $35-38$ \\
\hline $\begin{array}{l}\text { n } \\
\text { Sodium (mmol/l) } \\
\text { Potassium (mmol/l) } \\
\text { Urea (mmol/l) } \\
\text { Creatinine ( } \mu \mathrm{mol} / \mathrm{l}) \\
\text { Calcium (mmoll) } \\
\text { Phosphate (mmol/l) } \\
\text { Alkaline phosphatase } \\
\text { (IU/l) } \\
\text { Total protein (g/l) } \\
\text { Albumin (g/l) } \\
\text { Bilirubin ( } \mu \mathrm{mol} / \mathrm{l}) \\
\text { Aspartate } \\
\text { transaminase (IU/l) }\end{array}$ & $\begin{array}{l}79 \\
135 \\
(132-139) \\
3 \cdot 4 \\
(3 \cdot 2-3 \cdot 6) \\
3 \cdot 2 \\
(3 \cdot 0-3 \cdot 3) \\
43 \\
(40-47) \\
2 \cdot 42 \\
(2 \cdot 30-2 \cdot 55) \\
1 \cdot 05 \\
(0 \cdot 90-1 \cdot 15) \\
80 \\
(43-110) \\
64 \\
(60-68) \\
35 \\
(33-37) \\
<10 \\
<10\end{array}$ & $\begin{array}{l}38 \\
135 \\
(132-139) \\
3 \cdot 3 \\
(3 \cdot 0-3 \cdot 6) \\
3 \cdot 0 \\
(2 \cdot 9-3 \cdot 1) \\
47 \\
(45-49) \\
2 \cdot 34 \\
(2 \cdot 27-2 \cdot 40) \\
1 \cdot 13 \\
(1 \cdot 10-1 \cdot 17) \\
87 \\
(37-120) \\
63 \\
(60-66) \\
33 \\
(32-35) \\
<10 \\
<10\end{array}$ & $\begin{array}{l}18 \\
136 \\
(134-138) \\
3 \cdot 4 \\
(3 \cdot 2-3 \cdot 6) \\
3 \cdot 1 \\
(2 \cdot 9-3 \cdot 3) \\
45 \\
(43-47) \\
2 \cdot 32 \\
(2 \cdot 23-2 \cdot 40) \\
1 \cdot 00 \\
(0 \cdot 90-1 \cdot 10) \\
107 \\
(85-130) \\
63 \\
(60-66) \\
33 \\
(32-35) \\
<10 \\
<10\end{array}$ & $\begin{array}{l}22 \\
136 \\
(134-138) \\
3 \cdot 5 \\
(3 \cdot 4-3 \cdot 7) \\
2 \cdot 8 \\
(2 \cdot 5-3 \cdot 0) \\
42 \\
(40-44) \\
2 \cdot 30 \\
(2 \cdot 21-2 \cdot 40) \\
1 \cdot 02 \\
(0 \cdot 90-1 \cdot 10) \\
120 \\
(90-150) \\
62 \\
(60-64) \\
32 \\
(30-34) \\
<10 \\
<10\end{array}$ & $\begin{array}{l}25 \\
136 \\
(134-138) \\
3 \cdot 5 \\
(3 \cdot 3-3 \cdot 7) \\
2 \cdot 7 \\
(2 \cdot 4-3 \cdot 0) \\
39 \\
(37-42) \\
2 \cdot 25 \\
(2 \cdot 20-2 \cdot 30) \\
1 \cdot 01 \\
(0 \cdot 93-1 \cdot 10) \\
105 \\
(80-130) \\
60 \\
(58-62) \\
34 \\
(29-39) \\
<10 \\
<10\end{array}$ & $\begin{array}{l}162 \\
137 \\
(134-140) \\
3 \cdot 6 \\
(3 \cdot 4-3 \cdot 8) \\
2 \cdot 7 \\
(2 \cdot 5-3 \cdot 0) \\
38 \\
(36-40) \\
2 \cdot 24 \\
(2 \cdot 19-2 \cdot 29) \\
1 \cdot 00 \\
(0 \cdot 95-1 \cdot 10) \\
145 \\
(90-200) \\
60 \\
(58-62) \\
33 \\
(30-35) \\
<10 \\
<10\end{array}$ \\
\hline
\end{tabular}


Table 5 Analysis of variance of biochemical analytes using $\chi^{2}$ for the six gestational groups shown in Tables 3 and 4

\begin{tabular}{|c|c|c|c|c|}
\hline \multirow[t]{2}{*}{ Test } & \multicolumn{2}{|l|}{ Fetal } & \multicolumn{2}{|c|}{ Maternal } \\
\hline & $x_{3}^{2}$ & $p$ & $x_{5}^{2}$ & $p$ \\
\hline $\begin{array}{l}\text { Sodium } \\
\text { Potassium } \\
\text { Urea } \\
\text { Creatinine } \\
\text { Calcium } \\
\text { Phosphate } \\
\text { Total protein } \\
\text { Albumin } \\
\text { Bilirubin } \\
\text { Aspartate transaminase } \\
\text { Alkaline phosphatase }\end{array}$ & $\begin{array}{r}4 \cdot 7 \\
2 \cdot 5 \\
7 \\
13 \\
80 \\
11 \\
167 \\
41 \\
11 \\
8 \\
72\end{array}$ & $\begin{array}{l}\text { NS } \\
\text { NS } \\
<0.05 \\
<0.01 \\
<0.01 \\
<0.05 \\
<0.01 \\
<0.01 \\
<0.05 \\
<0.1 \\
<0.01\end{array}$ & $\begin{array}{r}4 \\
3 \\
16 \\
19 \\
40 \\
37 \\
10 \\
12 \\
4 \\
3 \\
16\end{array}$ & $\begin{array}{l}\text { NS } \\
\text { NS } \\
<0 \cdot 01 \\
<0 \cdot 01 \\
<0 \cdot 01 \\
<0 \cdot 01 \\
<0 \cdot 1 \\
<0 \cdot 05 \\
\text { NS } \\
\text { NS } \\
<0 \cdot 01\end{array}$ \\
\hline
\end{tabular}

NS $=$ not significant.

Table 6 Analysis of variance on the differences between biochemical analytes in maternal $(M)$ and fetal $(F)$ plasma throughout gestation

\begin{tabular}{lll}
\hline \multirow{2}{*}{ Test } & \multicolumn{2}{l}{ Analysis of variance on $M-F$} \\
\cline { 2 - 3 } & $F_{\mathbf{5 3 4 3}}$ & $p$ \\
\hline Sodium & 4 & $N S$ \\
Potassium & 5 & $\mathrm{NS}$ \\
Urea & 8 & $<0.05$ \\
Creatinine & 23 & $<0.001$ \\
Calcium & 35 & $<0.001$ \\
Phosphate & 19 & $<0.001$ \\
Total protein & 86 & $<0.001$ \\
Albumin & 92 & $<0.001$ \\
Bilirubin & 10 & 0.01 \\
Aspartate transaminase & 16 & 0.01 \\
Alkaline phosphatase & 90 & $<0.001$ \\
\hline
\end{tabular}

NS $=$ not significant.

concentrations decrease with advancing pregnancy as a result of altered renal haemodynamics as well as decreased protein catabolism. ${ }^{1314}$

\section{CALCIUM, PHOSPHATE, AND ALKALINE}

PHOSPHATASE

Fetal plasma calcium concentrations increased and maternal values decreased after about 20 weeks' gestation; before this the concentrations were not different $(t=0.2, p>0.05$ paired Student $t$ test $)$. Plasma phosphate concentrations in both maternal and fetal plasma showed a progressive but nonparallel decrease. Alkaline phosphatase in fetal plasma increased progressively throughout pregnancy, while the concentrations in maternal plasma showed no obvious pattern. The fetal enzyme was identified to be entirely of bone origin while the maternal enzyme was entirely placental.

It has long been known that fetal plasma calcium and inorganic phosphorus concentrations are higher than those in maternal plasma and that these substances, together with magnesium, are actively transported across the placenta. ${ }^{15}$ This specialised transport has been suggested to be facilitated by the placental calcium pump. ${ }^{16}$ It is therefore not surpris-

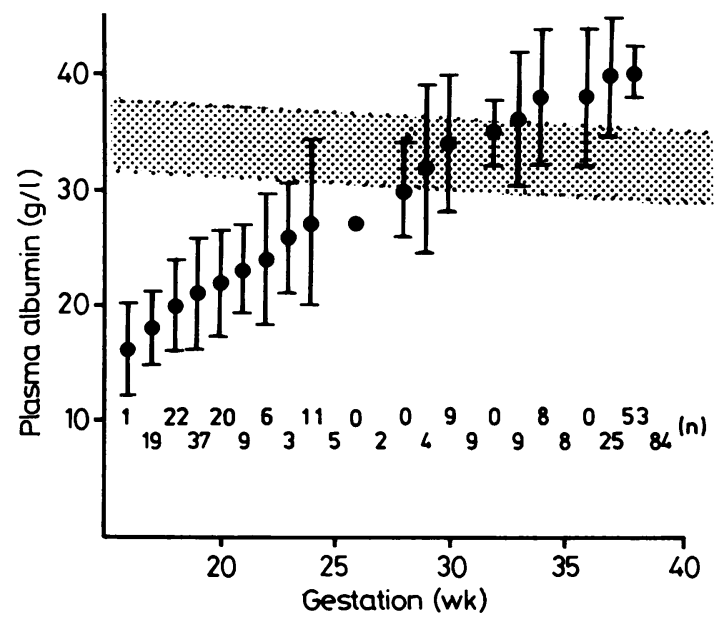

Fig. 1 Fetal plasma albumin concentrations (mean \pm 2 SD). Maternal range in shaded area.

ing that the plasma calcium and indeed fetal ionised calcium concentrations are higher in fetal blood (in preparation). The changes in fetal plasma phosphate concentration have been observed previously. ${ }^{17}$ The reason for this is unclear but is probably a consequence of high osteoblastic activity in the fetal bones, reflected by increases in alkaline phosphatase activity. In a normal pregnancy the fall in maternal plasma calcium and phosphate are probably due to plasma volume expansion. ${ }^{18}$

\section{TOTAL PROTEIN AND ALBUMIN}

Total protein and albumin concentrations in fetal plasma increased throughout gestation, while maternal values decreased (Figs. 1 and 2). Indeed the concentration of plasma proteins in the fetal circulation increased by more than half during gestation. By 12-16 weeks the fetal liver can synthesise all the plasma proteins except the gammaglobulins. ${ }^{14}$ Fetal plasma albumin concentrations begin increasing substantially from 20 weeks. There is suggestive 


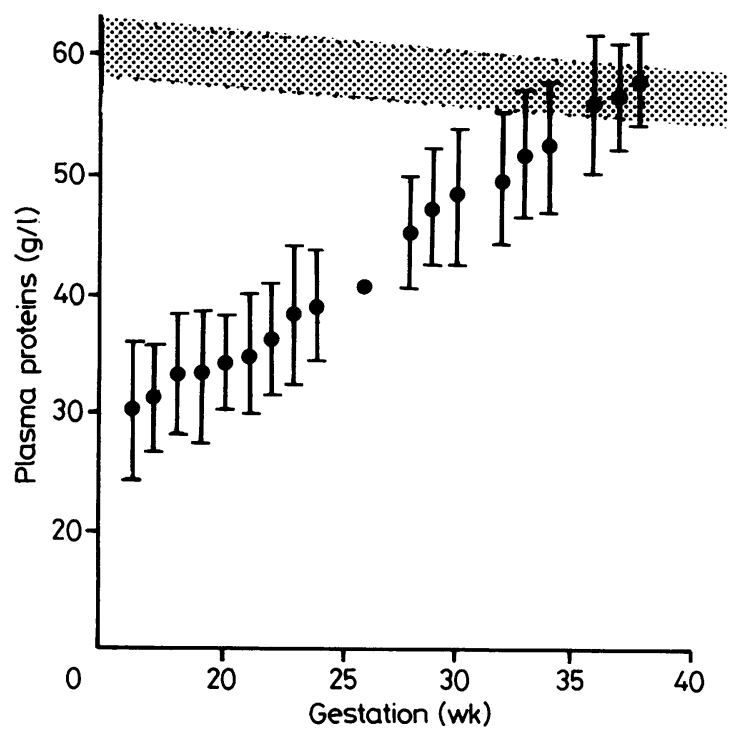

Fig. 2 Fetal plasma protein concentrations (mean $\pm S D$ ). Maternal range in shaded area.

evidence that fetal $\alpha$-fetoprotein synthesis is decreasing at this time ${ }^{20}$ and it is likely that albumin synthesis is switched on to become the major plasma protein in the circulation.

\section{ASPARTATE TRANSAMINASE AND BILIRUBIN}

These substances that reflect hepatic function were low in maternal blood throughout pregnancy. There were, however, small increases in fetal plasma, which in the case of aspartate transaminase could be due to leakage of this cytoplasmic enzyme from hepatic cells or else due to high concentrations of pyruvate in fetal blood which would consume $\mathrm{NADH}$ in the assay. When considering the causes of hyperbilirubinaemia, the life of the erythrocyte, the space in which bilirubin is distributed, as well as the glucuronide conjugating ability of the liver have to be taken into account. Fetal erythrocytes have a shortened life span of about 70 days $^{21}$ and the liver conjugating ability is still immature.

In this study the normal values of commonly measured biochemical substances relating to hepatic, renal, and bone function have been established in pure fetal blood samples. The concentrations of substances in blood at the time of sampling depend on a variety of factors, such as production and elimination rates and fluid distribution. Nevertheless, these values may be used as a reference range for pathophysiological investigations.

We thank Mr D Cooper, Senior Programmer and analyst, KCHMSD, for his advice.

\section{References}

' Rodeck $\mathrm{CH}$, Nicolaides $\mathrm{KH}$. Ultrasound guided invasive procedures in obstetrics. Clin Obstet Gynecol 1983;10:515-43.

${ }^{2}$ Rodeck CH, Campbell S. Sampling pure fetal blood by fetoscopy in the second trimester of pregnancy. $\mathrm{Br}$ Med J 1978;ii:72830.

${ }^{3}$ Nicolaides KH, Rodeck CH. Fetoscopy. Br J Hosp Med 1984;35:396-405.

${ }^{4}$ Rodeck CH, Nicolaides KH. Fetoscopy and fetal tissue sampling. Br Med Bull 1983;39:332-7.

${ }^{5}$ Whitehead TP, Browning DM, Gregory A. The role of External Quality Control Schemes in improving the quality of laboratory results. In: Anido G, van Kampers EJ, Rosalki SB, Rubin $M$. eds, Quality control in clinical chemistry. New York: Walter de Gruyter, 1975;131-141.

- Deverill I. Kinetic measurement of the immunoprecipitation reaction using the centrifugal analyser. In: Price $\mathrm{CP}$, Spencer $\mathrm{K}$, eds. Centrifugal analysers in clinical chemistry. East Sussex: Praeger Publishers, 1980:109-115.

${ }^{7}$ Whitby LG, Moss DW. Analysis of heat inactivation curves of alkaline phosphatase isoenzymes in serum. Clin Chim Acta 1975; 59:361-7.

${ }^{8}$ Harris EK, De Mets DL. Estimation of normal ranges as cumulative proportions by transferring observed distributions to gaussian form. Clin Chem 1972;18:605-12.

${ }^{4}$ Hytten FE. Water transfer. In: Chamberlain GVP, Wilkinson AW, eds. Placental transfer, Tunbridge Wells: Pitman Medical, 1979:90-5.

${ }^{10}$ Flexner LB, Cowie DB, Hellman LM, Wilde WS, Vosburgh GJ. The permeability of the human placenta to sodium in normal and abnormal pregnancies and the supply of sodium to the human fetus as determined with radioactive sodium. Am J Obst Gynaecol 1948;55:469-73.

"Battaglia FC, Meschia G. Fetal metabolism and substrate utilization. In: Comline RS, Cross KW, Davies GA, Nathanielsz PW, eds. Fetal and neonatal physiology. Barcroft Centenary Symposium. Cambridge: Cambridge University Press, 1973:38297.

${ }^{12}$ Cook JGH. Factors influencing the assay of creatinine. Ann Clin Biochem 1975;12:219-32.

${ }^{13}$ Robertson EG, Cheyne GA. Plasma biochemistry in relation to oedema of pregnancy. Br J Obstet Gynaecol 1972;79:769-73.

${ }^{14}$ Kühlback B, Widholm O. Plasma creatinine in normal pregnancy. Scand Lab Invest 1966;18:654-6.

is Reitz RE, Doane TA, Woods JR, Weinstein RC. Calcium, magnesium, phosphorus and parathyroid hormone interrelationships in pregnancy and newborn infants. Obstet Gynecol 1977; 50:701-4.

16 Ramsey GR Jnr, Delivoria-Papodopoulos M, Crandell ED, Kronfield DA. Kinetic analysis of calcium transport across the placenta. J Appl Physiol 1.973;35:682-93.

${ }^{17}$ Assali NS. The fetus and neonate. In: Assali NS, eds. Biology of gestation. Vol 2. London: Academic Press, 1968:25-30.

${ }^{18}$ Pitkin RM. Calcium metabolism in pregnancy: A review. Am J Obstet Gynecol 1975;121:724-37.

${ }^{14}$ Dancis J, Brauerman N, Lind J. Plasma protein synthesis in the human fetus and placenta. J Clin Invest 1957;36:398-404.

${ }^{20}$ Gitlin D, Pernicells A, Gitlin GM. Synthesis of $\alpha$-feto protein by the liver, yolk-sac and gestational tract of the human conceptus. Cancer Res 1972;32:979-82.

${ }^{21}$ Pearson HA. Life span of fetal red blood cells. $J$ Pediatr 1971;70:166-77.

Requests for reprints to: Dr C Moniz, Department of Chemical Pathology, King's College Hospital, Denmark Hill, London SE5 9RS, England. 